\title{
Inhibition of Inducible Nitric Oxide Controls Pathogen Load and Brain Damage by Enhancing Phagocytosis of Escherichia coli K1 in Neonatal Meningitis
}

Rahul Mittal, ${ }^{*}$ Ignacio Gonzalez-Gomez, ${ }^{\ddagger}$ Kerstin A. Goth,§ and Nemani V. Prasadarao*‡

From the Division of Infectious Diseases," the Departments of Pathology, ${ }^{\dagger}$ and Surgery, ${ }^{\Im}$ The Saban Research Institute, Childrens Hospital Los Angeles, and the Keck School of Medicine, ${ }^{\ddagger}$ University of Southern California, Los Angeles, California

Escherichia coli $\mathrm{K} 1$ is a leading cause of neonatal meningitis in humans. In this study, we sought to determine the pathophysiologic relevance of inducible nitric oxide (iNOS) in experimental E. coli $\mathrm{K} 1$ meningitis. By using a newborn mouse model of meningitis, we demonstrate that $E$. coli infection triggered the expression of iNOS in the brains of mice. Additionally, iNOS ${ }^{-/}$mice were resistant to $E$. coli $\mathrm{K1}$ infection, displaying normal brain histology, no bacteremia, no disruption of the blood-brain barrier, and reduced inflammatory response. Treatment with an iNOS specific inhibitor, aminoguanidine (AG), of wild-type animals before infection prevented the development of bacteremia and the occurrence of meningitis. The infected animals treated with $A G$ after the development of bacteremia also completely cleared the pathogen from circulation and prevented brain damage. Histopathological and micro-CT analysis of brains revealed significant damage in $E$. coli K1-infected mice, which was completely abrogated by AG administration. Peritoneal macrophages and polymorphonuclear leukocytes isolated from iNOS $^{-1-}$ mice or pretreated with AG demonstrated enhanced uptake and killing of the bacteria compared with macrophages and polymorphonuclear leukocytes from wild-type mice in which $E$. coli $\mathrm{K} 1$ survive and multiply. Thus, NO produced by iNOS may be beneficial for $E$. coli to survive inside the macrophages, and prevention of iNOS could be a therapeutic strategy to treat neonatal $E$. coli meningitis. (Am J Pathol 2010, 176:1292-1305; DOI: 10.2353/ajpath.2010.090851)
Bacterial meningitis is a fatal and serious infection of the central nervous system (CNS). ${ }^{1,2}$ The underlying pathophysiological mechanisms implicated in the development of meningitis are quite complex and remain poorly understood. Bacterial meningitis is associated with high mortality and morbidity, even when treated with antibiotics. ${ }^{3,4}$ The mortality occurs in $25 \%$ to $35 \%$ of all patients, and long-term neurological and neuropsychological sequelae are reported to affect up to $50 \%$ of survivors. ${ }^{5,6}$ These complications include intracranial hypertension caused by brain edema or hydrocephalus, arterial and venous cerebrovascular alterations (cerebral ischemia, venous thrombosis), intracranial hemorrhage, mental retardation, focal neurological deficits, hearing impairment, and systemic spread of bacteria leading to septic shock and multiorgan failure. ${ }^{7,8}$ Escherichia coli $\mathrm{K} 1$ is one of the most common pathogens that causes sepsis and meningitis during neonatal period. ${ }^{9-12}$ The emergence of multidrug resistant $E$. coli $\mathrm{K} 1$ has further increased the incidence of these infections. ${ }^{13-15}$ Numerous mediators have been implicated in the complex pathophysiologic processes of E. coli $\mathrm{K} 1$ meningitis such as inflammatory cytokines, arachidonic acid metabolites, platelet-activating factor, and nitric oxide (NO). ${ }^{16}$

NO has been shown to play an important role in the pathophysiology of meningitis. ${ }^{17,18} \mathrm{NO}$ is biosynthesized from L-arginine through the action of NO synthase (NOS). ${ }^{19}$ Three different forms of NOS have been identified: endothelial NOS (eNOS, or NOS III), neuronal NOS (nNOS, or NOS I), and inducible NOS (iNOS, or NOS II). ${ }^{20}$ eNOS and nNOS are constitutively expressed in the brain and play an important role in neurotransmission. ${ }^{21}$ Gen-

\footnotetext{
Supported by NIH grant Al40567 (to N.V.P.).

Accepted for publication November 5, 2009

Supplemental material for this article can be found on http://ajp. amjpathol.org.

Address reprint requests to Nemani V. Prasadarao, Ph.D., Division of Infectious Diseases, MS \#51, Childrens Hospital Los Angeles, 4650 Sunset Blvd, Los Angeles, CA 90027. E-mail: pnemani@chla.usc.edu.
} 
erally, iNOS is absent in the resting cells and is triggered in response to stimuli such as bacteria or proinflammatory cytokines and lead to the production of greater amounts of NO. ${ }^{22,23}$ iNOS activity has been demonstrated in a wide variety of stimulated cells like macrophages, neutrophils, vascular smooth cells, and glial cells in the CNS. ${ }^{24,25}$ During microbial infections, excessive NO produced by iNOS has diverse functions ranging from antimicrobial and anti-inflammatory host defense and cytoprotection to proinflammatory and cytotoxic activities. ${ }^{26,27}$ The nature of the pathological insults and the physiological environment of infections govern which of two opposite roles NO will play: either defense of the host or impairment of host defense so that pathogenesis of the invading microbes is supported. ${ }^{28,29}$ The host defense function of $\mathrm{NO}$ is best characterized by antimicrobial and cytoprotective activities that have been observed in bacterial, fungal, and parasitic infections. ${ }^{30}$ In contrast, NOmediated inflammation and pathogenesis have been documented in several diseases including arthritis, encephalitis, ulcerative colitis, and viral infections. ${ }^{31-33} \mathrm{NO}$ has also been implicated in alterations in cerebral vascularity. ${ }^{34}$ Elevated concentrations of nitrite/nitrate and other stable metabolites of NO have been demonstrated in the cerbrospinal fluid (CSF) of meningitis patients during the acute stage of the disease. ${ }^{18}$ Moreover, an increased NO production has been observed in animal models of bacterial meningitis. ${ }^{35}$

Our studies using human brain microvascular endothelial cells (HBMECs) revealed that E. coli invasion induces the production of $\mathrm{NO}$, which is in turn responsible for enhanced invasion of the bacteria into HBMECs, an in vitro model of the blood-brain barrier (BBB). ${ }^{36}$ Therefore, we hypothesize that NO might be responsible for the brain damage in the pathogenesis of meningitis and plays a crucial role in the disruption of the BBB. In this study, we established a mouse of model of $E$. coli meningitis using C57BL/6 mice and used $\mathrm{iNOS}^{-1-}$ mice to determine the role of $\mathrm{NO}$ in experimental E. coli $\mathrm{K} 1$ meningitis. A compelling observation of these studies is that lack of iNOS expression is protective against E. coliinduced meningitis, and treating the animals with iNOS inhibitor completely prevented E. coli-induced brain damage by enhancing the killing of bacteria by macrophages and reducing the pathogen load.

\section{Materials and Methods}

\section{Bacterial Strains, Antibodies, and Other Reagents}

E. coli $\mathrm{E} 44\left(\mathrm{OmpA}^{+}\right.$E. coli) is a rifampicin-resistant mutant of $E$. coli $\mathrm{K} 1$ strain RS 218 (serotype 018:K1:H7), which was isolated from the cerebrospinal fluid of a neonate with meningitis and invades human brain microvascular endothelial cells in vitro. ${ }^{37}$ Bacteria were grown in Luria broth (LB; DIFCO Laboratories) with appropriate antibiotics. Antibodies to iNOS, eNOS, and $\beta$ actin were obtained from BD Biosciences (San Diego, CA) and Santa Cruz Biotechnology (San Diego, CA), respectively. All other reagents were purchased from Sigma. Antibodies to CD64, CR3 were obtained from BD Biosciences (San Diego, CA) whereas TLR4 and TLR2 were obtained from Imgenex (San Diego, CA). Anti-gp96 antibodies were generated in our laboratory as described earlier. ${ }^{37}$

\section{Animals}

Breeding pairs of C57BL/6 $\mathrm{iNOS}^{-1-}$ mice and wild-type C57BL/6 mice were obtained from Jackson Laboratories (Bar Harbor, ME). The colony was maintained by intercrossing iNOS ${ }^{-1-}$ male and female (homozygous) mice. Offspring was tested by PCR of tail DNA for the presence or absence of iNOS gene.

\section{Newborn Mouse Model of Meningitis}

The animal studies were approved by the IACUC of $\mathrm{CHLA}$ and followed National Institutes of Health guidelines for the performance of animal experiments. Threeday-old mouse pups were randomly divided into various groups and infected intranasally with $10^{3} \mathrm{cfu}$ of bacteria. Control mice received pyrogen free saline through the same route. To assess the effect of aminoguanidine (AG) on E. coli meningitis, AG (10 mg/kg body weight) was injected intraperitoneally (IP) 24 hours postinfection and two more similar doses at 6-hour intervals after initial dose. In another group, mice were pretreated with $A G$ via IP injection (10 $\mathrm{mg} / \mathrm{kg}$ body weight). A total of four doses were given at an interval of 12 hours in a two-day period before infection. Blood was collected from the tail or facial vein at different time periods of postinfection, dilutions were made, and plated on rifampicin LB agar plates to ensure bactremia and success of infection. CSF samples were collected aseptically under anesthesia by cisternal puncture and directly inoculated into broth containing antibiotics. Mice were perfused by intracardiac route with $0.9 \%$ saline to remove blood and contaminating intravascular leukocytes. Brain, liver, spleen, lung, kidney, and intestine were aseptically removed and homogenized in sterile PBS. Bacterial counts in these organs were determined by plating ten-fold serial dilutions on rifampicin LB agar plates. Growth of $E$. coli in rifampicin containing LB broth from CSF samples was considered positive for meningitis.

\section{Histopathology}

Half of the brain was fixed in $10 \%$ buffered formalin, routinely processed, and embedded in paraffin. ${ }^{38}$ Fourto $5-\mu \mathrm{m}$ sections were cut using Leica microtome and stained with hematoxylin and eosin (H\&E) or prepared for immunohistochemistry. Pictures were taken using Zeiss Axiovert Microscope connected to a JVC 3-chip color video camera and read by the pathologist in a blinded fashion.

\section{Immunohistochemistry}

For immunohistochemistry staining, the paraffin was extracted from the sections with a 5-minute wash in 100\% 
xylene. Samples were treated for 10 minutes with 70\% ethanol, followed by 5-minute treatments each with 95\% ethanol, $100 \%$ ethanol, and distilled water. Sections were microwaved at high temperature in antigen unmasking solution for 2 to 3 minutes (Vector Laboratories, Burlingame, CA) and then allowed to cool for antigen retrieval. Endogenous peroxidases were quenched by incubation with $7.5 \%$ hydrogen peroxidase in water for 5 minutes. Samples were incubated with PBST $(0.1 \mathrm{M}$ PBS plus $0.01 \%$ triton $\times 100$ ) containing $5 \%$ normal donkey serum to block non-specific binding followed by incubation with a 1:1000 dilution of iNOS antibody for 30 minutes. Samples were then rinsed with PBST containing $1 \%$ normal donkey serum, incubated with a 1:500 dilution of goat anti-rabbit $\operatorname{lgG}(\lg G)$-biotin for 30 minutes and then again, rinsed with PBST. The bound antibody was visualized by probing with streptavadin-horseradish peroxidase followed by diaminobenzidine and hydrogen peroxide, which yields a brown reaction product. Counterstaining was performed using Mayer hematoxylin.

\section{Estimation of NO Production}

Concentration of nitrite in the brain tissues was measured as an index for NO production. Equal weights of the brains of infected mice were homogenized in sterile PBS $(1 \mathrm{ml})$, supernatants were collected, and analyzed for NO production by modified Greiss method as described earlier. ${ }^{39}$ Briefly, nitrate was converted to nitrites with $\beta$-nicotinamide adenine dinucleotide phosphate (NADPH; $1.25 \mathrm{mg} / \mathrm{ml}$ ) and nitrate reductase followed by addition of Griess reagent. The reaction mixture was incubated at room temperature for 20 minutes followed by addition of TCA. Samples were centrifuged, clear supernatants were collected, and optical density was recorded at $550 \mathrm{~nm}$. The amounts of NO produced were determined by calibrating a standard curve using sodium nitrite.

\section{Detection of iNOS Expression in the Brain by Flow Cytometry}

To detect the expression of iNOS by flow cytometry, brains were removed, transferred to ice-cold Hanks buff$\mathrm{er} / 3 \%$ fetal calf serum, homogenized using a glass potter, and passed through a stainless-steel sieve. The dissociated sample was collected by centrifugation and was digested for 60 minutes at $37^{\circ} \mathrm{C}$ with $1.4 \mathrm{ml}$ of $0.75 \%$ (w/v) with type II collagenase (0.95 unit/mg, Sigma) and $10^{4}$ units of DNase I (Sigma) in dissociation buffer $(42 \mathrm{mmol} / \mathrm{L}$ $\mathrm{MgCl}_{2} / 23 \mathrm{mmol} / \mathrm{L} \mathrm{CaCl}_{2} / 50 \mathrm{mmol} / \mathrm{L} \mathrm{KCl} / 153 \mathrm{mmol} / \mathrm{L}$ $\mathrm{NaCl}$ ). The digested sample was pelleted and resuspended in PBS. The cells were first preincubated for 30 minutes with IgG blocking buffer to mask nonspecific binding sites, fixed with $2 \%$ paraformaldehyde, and permeabilized using BD cytofix and cytoperm kit. Cells were then incubated with iNOS or an isotype control antibody for 30 minutes at $4{ }^{\circ} \mathrm{C}$ and then washed with $\mathrm{BD}$ permwash buffer. FITC-conjugated secondary antibody was then added, incubated for 20 minutes at $4^{\circ} \mathrm{C}$, and washed with permwash buffer. The stained cells were then analyzed by flow cytometry using FACS calibur Cell Quest Pro software (BD Biosciences, San Diego, CA), and at least 10,000 events were collected for analysis. Results are expressed as mean fluorescence intensity subtracted from isotype matched control.

\section{RT-PCR}

For detection of iNOS and eNOS by RT-PCR, frozen brains from infected wild-type, iNOS ${ }^{-1-}$, and control mice were cut with a cryostat. Total RNA was isolated from frozen sections containing lateral ventricles and hippocampal tissue with TRIZOL-LS-reagent (Gibco BRL, Gaithersburg, MD). RNA was quantified using a nanodrop machine. RT-PCR for iNOS and eNOS was performed using the following primer sequences: 5' (sense) 5'-GCCTCGCTCTGGAAAGA-3'; 3' (antisense) 5'-TCCATGCA GACAACCTT-3' and $5^{\prime}$ (sense) 5'-CAGTGTCCAACATGCTGCTGGAAATTG-3'; 3' (antisense) 5'-TAAAGGTCTTCTTCCTGGTGATGCC-3', respectively. Mouse glyceraldehyde-3-phosphate dehydrogenase (GAPDH) was used as an internal control, using the following primer sequences: GAPDH sense, 5'-CATCACCATCTTC CAGGAGCG-3' and GAPDH antisense, 5'GAGGGGCCATCCACAGTCTTC-3'. Negative controls without RT were performed in parallel for every reaction, to exclude amplification of contaminating DNA. The amplified products were separated on a $1 \%$ agarose gel and were stained with ethidium bromide. The gels were photographed and optical densities were determined by using a computer imaging analysis system (Visitron Systems $\mathrm{GmbH}$ ). RT-PCR was performed in duplicates, and the mean density of PCR products was determined, to calculate the ratio to GAPDH.

\section{Determination of BBB Leakage}

The BBB permeability was quantitatively evaluated by detection of extravasated Evans blue dye. ${ }^{40}$ Briefly, $2 \%$ Evans blue dye in saline was injected intraperitoneally, and after 4 hours mice were deeply anesthetized with Nembutal and transcardially perfused until colorless perfusion fluid was obtained from the right atrium. After decapitation, brain tissue was removed, weighed, and homogenized. The supernatant was obtained by centrifugation, and protein concentration was determined. Evans blue intensity was determined by a microplate reader at $550 \mathrm{~nm}$. Calculations were based on the external standards dissolved in the same solvent. The amount of extravasated Evans blue dye was quantified as micrograms per milligram protein.

\section{Whole Blood Survival Assay}

To perform bactericidal assays using whole blood, $12 \mu \mathrm{l}$ of $100 \mathrm{mmol} / \mathrm{L} \mathrm{CaCl}_{2}$ in the presence of heparin $(2 \mathrm{U} / \mathrm{ml})$ was added to $1 \mathrm{ml}$ of citrated blood and aliquots of blood were incubated with bacteria $\left(10^{6} \mathrm{cells}\right)$ at $37^{\circ} \mathrm{C}$ for varying periods. The experiments were repeated for at least five times in triplicates. 


\section{Isolation of Peritoneal Macrophages and} Polymorphonuclear Leukocytes from Mice

Peritoneal macrophages were isolated from mice according to the method of Mittal et al..$^{41}$ Briefly, mice peritoneal cavity was exposed carefully without disrupting blood vessels, and 2 to $3 \mathrm{ml} \mathrm{RPMI}$ was slowly injected. The lavage was sucked back and cultured in tissue culture flasks for 2 hours at $37^{\circ} \mathrm{C}$ under $5 \% \mathrm{CO}_{2}$ to allow adherence of macrophages. The nonadherent cells were removed and flasks were washed three times with Hanks solution. The adherent cells were harvested from the flask by using a rubber policeman and were resuspended in 10\% FCS-RPMI 1640 medium. Macrophages were then positively selected using Miltenyi biotech kit and percentage purity was examined by FACS analysis using F4/80 antibody, which was $>95 \%$. Viability of macrophages after interaction with bacteria was assessed by Annexin V kit according to manufacturer's instructions (BD Biosciences, San Diego, CA). Polymorphonuclear leukocytes (PMNs) were isolated from mice as described previously. ${ }^{42}$ The purity of PMNs was examined by flow cytometry using Gr-1 antibody, which was $>95 \%$.

\section{Detection of Surface Molecule Expression on Macrophages}

The expression of TLR2, TLR4, CR3, Fc $\gamma$ l (CD64), and GP96 on the surface of wild-type, iNOS ${ }^{-1-}$ and AG pretreated macrophages $(0.5 \mathrm{mmol} / \mathrm{L})$ or isolated from infected mice was determined by flow cytometry. In brief, macrophages were infected with bacteria for six hours and then washed. The cells were first preincubated for 30 minutes with IgG blocking buffer to mask nonspecific binding sites and then fixed using BD cytofix reagent. Cells were then incubated with antibodies to TLR2, TLR4, CR3, CD64, and GP96 or an isotype control antibody for 30 minutes at $4^{\circ} \mathrm{C}$ and then washed with PBS. Then respective FITC conjugated secondary antibodies were added, incubated for 20 minutes at $4^{\circ} \mathrm{C}$, and washed with PBS. The stained cells were then analyzed by flow cytometry using FACS calibur Cell Quest Pro software (BD Biosciences, San Diego, CA), and at least 10,000 events were collected for analysis. Macrophages were gated using F4/80 as a gating marker. Results are expressed as mean fluorescence intensity subtracted from isotype matched and respective uninfected controls.

\section{Mouse Brain Micro-CT Imaging (Virtual Histology)}

The formalin-fixed specimens were sent to Numira Biosciences (Salt Lake City, UT) for micro-CT imaging. Specimens were stained with a proprietary contrast agent. A high-resolution volumetric micro-CT scanner ( $\mu$ CT40 ScanCo Medical, Zurich, $\mathrm{CH}$ ) was used to scan the tissue with the following parameters: $10 \mu \mathrm{m}$ isometric voxel resolution at $200 \mathrm{~ms}$ exposure time, 2000 views and 10 frames per view. The micro-CT generated DICOM files were converted into a file format compatible with the image processing software applications. Using Teem (Version 1.10.0; http://teem.sourceforge.net/), SCIRun (Scientific and Computing Imaging Institute, University of Utah), and Numira proprietary software tools, images of the samples were generated.

\section{Cytokines Determination}

The levels of TNF- $\alpha$, IL-1 $\beta$, IL-6, and IL-12p70 were measured in blood and brain homogenates of mice pups infected with E. coli using ELISA kits from Biosource (Carlsbad, CA) according to the manufacturer's instructions.

\section{Statistical Analysis}

For statistical analysis of the data, two-tailed Fisher test, Wilcoxon signed rank test, and Student $t$ test was applied, and $P$ values $<0.05$ were considered statistically significant.

\section{Results}

\section{Elevated NO Production in the Brain of Mice Infected Intranasally with $\mathrm{E}$. coli $\mathrm{K} 1$}

Previous studies from our lab have utilized a newborn rat model of meningitis by infecting the rat pups by intracardiac route in which the pathology of the brain mimics human brain pathology attributable to $E$. coli meningitis. ${ }^{43}$ Because the rat model circumvents several bacterial interactions with host tissues during the initial stages of infection, we set out to establish a mouse model of meningitis by intranasal infection in this study, such as to take advantage of various knockout animals for subsequent investigations. The brain pathology of wild-type mice infected with $E$. coli revealed inflammatory infiltrates of PMNs in the leptomeningeal and ventricular spaces (Figure 1A). Hippocampus showed severe inflammation and apoptosis of neurons in the Ammon horn. Acute hemorrhage, most prominent in the white matter of the brain, was observed. Cortex and molecular layer showed increased cellularity attributable to inflammatory exudates. Similar results were also observed with rat pups infected with E. coli intranasally (see Supplemental Figure S1 at http://ajp.amjpathol.org), indicating that mouse and rat brain damage induced by $E$. coli is very similar. All animals infected with $E$. coli were positive for meningitis by 72 hours postinfection and succumbed between 96 and 120 hours, whereas animals infected with a nonvirulent strain HB101 showed no meningitis and survived (Table 1). In addition, significantly higher NO production in infected brains was observed in comparison with the brains of uninfected mice or animals inoculated with saline as assessed by Griess reagent (Figure 1B; $P<0.01$ by Student $t$ test). NO levels increased from $23 \mu \mathrm{g} / \mathrm{g}$ brain tissue at 12 hours to $80 \mu \mathrm{g} / \mathrm{g}$ brain tissue by 72 hours postinfection. Flow cytometry analysis of brain tissue ho- 
A

\section{Cortex and Meninges}

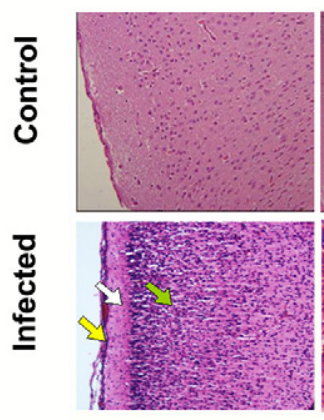

B

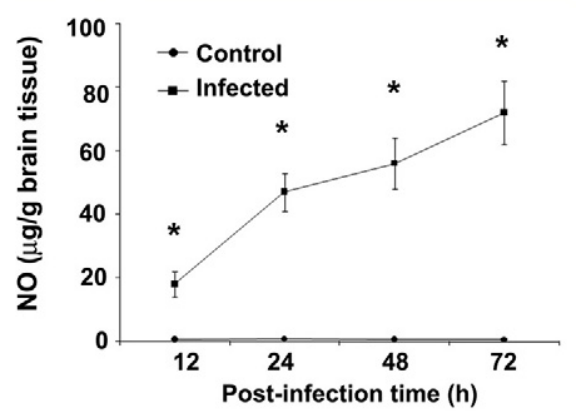

D

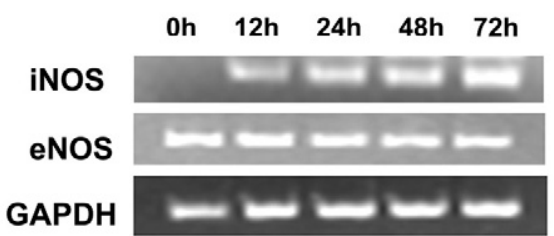

White matter Choroid plexus

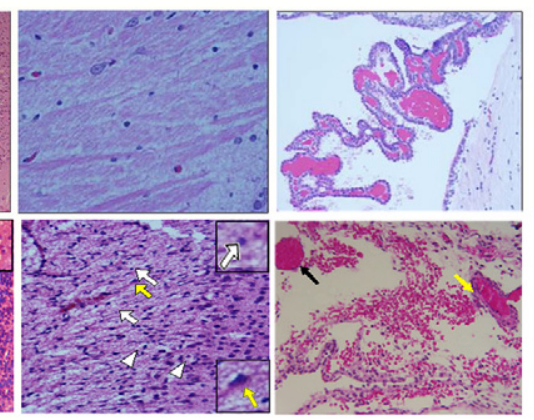

C

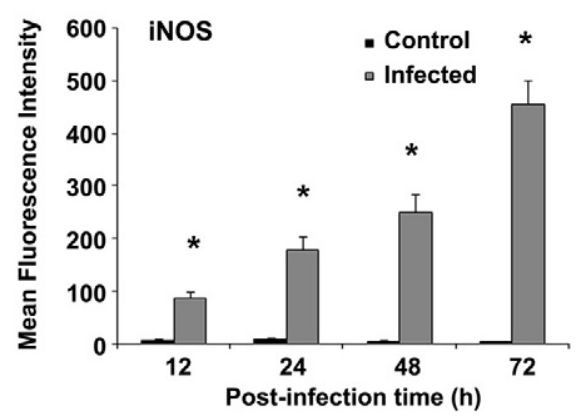

E

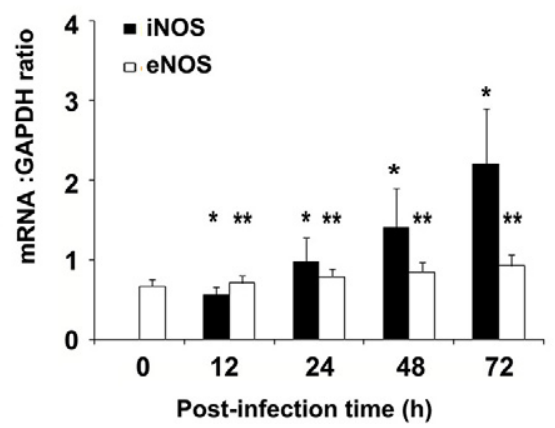

Figure 1. NO production in E. coli $\mathrm{K} 1$ mouse model of neonatal meningitis. Three-day-old mouse pups were infected intranasally with $10^{3}$ cfu of E. coli, and brains were subjected to histopathological examination after staining with H\&E as described in the Materials and Methods Significant pathological alterations in the brain of $E$. coli-infected pups compared with uninfected control animals were observed (A). Inflammation (green arrow) and increased cellularity (white arrow) were seen in cerebral cortex as well as in leptomeninges (yellow arrow) in the brain tissues of $E$. coli-infected mice. Hippocampus showed severe inflammation (white arrow) and apoptosis (yellow arrow enlarged in inset) particularly in the Ammon horn. Severe gliosis with prominent astrocytic processes (yellow arrows; enlarged in inset) polymorphonuclear cells (white arrows; enlarged in inset), and scattered apoptotic cells (arrowhead) with rarified background were observed in the white matter. There was acute hemorrhage in choroid plexus disrupting the loose connective tissue stroma. The vascular structures were congested (black arrow) and inflammation was noted in perivascular location (yellow arrow). The pictures are representative of an infected group of 18 animals (magnification $\times 20$ ). In addition, NO production $(\mathbf{B})$ and iNOS expression $(\mathbf{C})$ were determined by Griess reagent and flow cytometry, respectively, in the brain tissues of infected mice. Results are given as the mean \pm SEM and are representative of five independent experiments. The increase in the production of $\mathrm{NO}$ was significantly greater in infected mice, ${ }^{*} P<0.001$ by Student $t$ test. Furthermore, mRNA levels of eNOS, iNOS, or GAPDH at $0,12,24,48$, and 72 hours after infection were assessed by RT-PCR in the brain specimens of mice using specific primer pairs (D). The transcription levels were determined by densitometry of iNOS and eNOS bands from three different experiments and mean values are expressed as a ratio of NOS and GAPDH $(\mathbf{E}) .{ }^{*} P<$ 0.05 compared with 0 hours for iNOS and ${ }^{* * *} P>$ 0.05 , compared with 0 hours in case of eNOS mogenates revealed a fourfold increase in the expression of iNOS at 72 hours compared with the levels at 12 hours postinfection (Figure 1C). To examine whether there was an increase in iNOS transcription during the infection, RNA was extracted from brain tissues and subjected to RT-PCR using iNOS and eNOS primers. The constitutive expression of eNOS but not iNOS in uninfected animals was observed by RT-PCR (Figure 1D). However, infection with $E$. coli was associated with increased expression of iNOS as early as 12 hours postinfection and further in-

Table 1. Occurrence of Meningitis in Newborn Mice Infected with E. coli

\begin{tabular}{cccc}
\hline $\begin{array}{c}\text { Bacterial } \\
\text { strains }\end{array}$ & $\begin{array}{c}\text { Number } \\
\text { of } \\
\text { animals }\end{array}$ & $\begin{array}{c}\text { Bacteremia* }\left(\log _{10}\right. \\
\text { CFU/ml of blood) } \\
\text { culture }(\%)\end{array}$ & $\begin{array}{c}\text { Number of } \\
\text { animals with } \\
\text { positive CSF }\end{array}$ \\
\hline E. coli K1 & 18 & $8.31 \pm 1.54$ & $17(94 \%)$ \\
HB 101 & 18 & $0 \pm 0$ & $0^{+}(0 \%)$ \\
\hline
\end{tabular}

${ }^{*}$ Counts 72 hours postinfection.

${ }^{\dagger} P<0.001$ E. coli $\mathrm{K} 1$ versus HB101. creased by 72 hours. Quantitative analysis of PCR products normalized to GAPDH levels revealed that peak transcription of iNOS was at 72 hours postinfection (Figure 1E). In contrast, no significant increase in the expression of eNOS was observed ( $P>0.05$ by Student $t$ test). To determine the localization of iNOS expression in the infected brain, immunohistochemical analysis was performed. Uninfected animals showed no detectable reactivity to iNOS antibodies in any region (Figure 2, A, C, and E). A marked increase in iNOS staining was observed, however, in infected animals at time points ranging from 48 to 72 hours postinfection and was strongly associated with white matter and meningeal vessel wall (Figure 2, B and D). Within the brain parenchyma of infected mice, but not control animals, only a few cells positive for iNOS were found in superficial areas of the cortex, most likely representing inflammatory infiltration associated with cortical injury (Figure 2F). These results suggest that $E$. coli meningitis is associated with an increased production of $\mathrm{NO}$ attributable to enhanced expression of iNOS in brains of infected animals. 
Uninfected
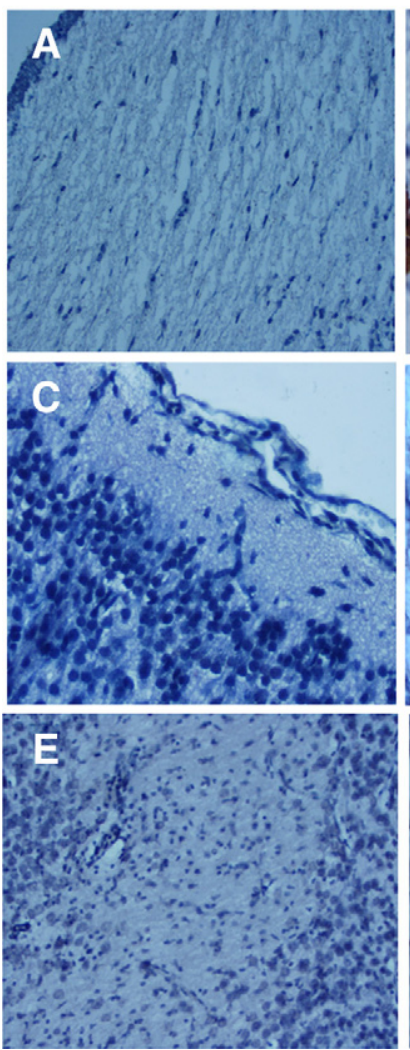

Infected
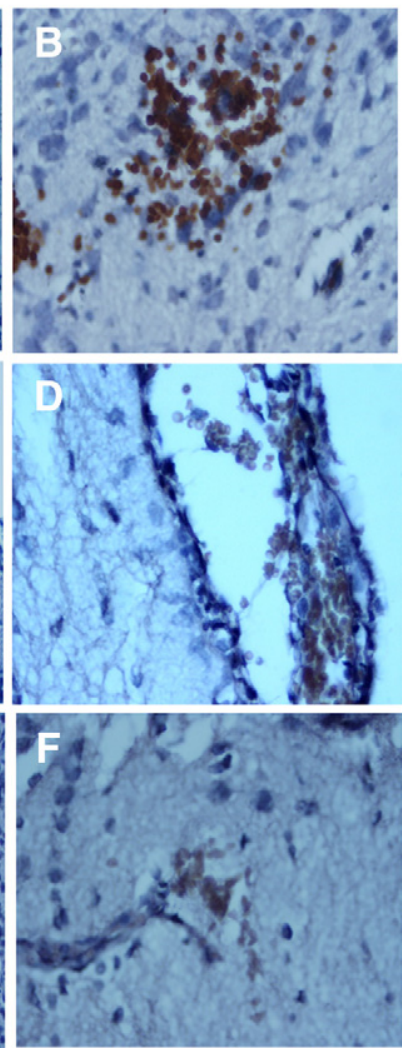

Figure 2. Localization of iNOS expression in the brain tissues of $E$. col K1-infected mice. Tissue sections of brains of uninfected or infected mice were stained with anti-iNOS antibody followed by horseradish peroxidase conjugated secondary antibody. The color was developed by using a mixture of diaminobenzidine and hydrogen peroxide as described in the Materials and Methods. A strong immunoreactivity indicating the presence of iNOS (brown color) was observed in the white matter (B) and along the meningeal vessel wall (D), whereas faint iNOS-positive staining was demonstrable in the brain parenchyma $(\mathbf{F})$. No iNOS staining was observable in brains of control uninfected mice $(\mathbf{A}, \mathbf{C}$, and $\mathbf{E}$; magnification, $\times 20)$

\section{iNOS $^{-/-}$Mice Are Resistant to E. coli K1 Meningitis}

To further address the role of NO in E. coli meningitis, iNOS $^{-1-}$ mice were infected and various parameters of the disease examined. The bacterial load was examined in the blood of mice at different postinfection times. E. coli entered the blood of infected wild-type mice as early as 2 hours postinfection and increased to $7.0 \log _{10} \mathrm{cfu} \mathrm{ml}^{-1}$ by 72 hours (Figure 3A). In contrast, the bacterial load peaked to $2.45 \log _{10} \mathrm{cfu} \mathrm{ml}^{-1}$ by 4 hours in iNOS ${ }^{-1-}$ mice and started clearing from the blood to undetectable levels by 12 hours postinfection. Of note, the levels of $\mathrm{NO}$ production in iNOS $^{-1-}$ animals infected with E. coli were completely absent, whereas wild-type animals showed robust production of NO (Figure 3B). These results suggest that the bacteria that entered the blood of iNOS ${ }^{-1-}$ mice might be killed in a more efficient manner and consequently cleared from circulation. We next evaluated whether the bacteria that entered the blood might have been trapped in various organs by examining the bacterial load in intestine, spleen, liver, lung, kidney, and brain. No bacterial counts were observed in any of these organs from iNOS ${ }^{-1-}$ mice although wild- type mice showed significant bacterial loads in these organs (Figure 3, C and D, and see Supplemental Figure S2 at $h$ ttp://ajp.amjpathol.org). In these figures, results from iNOS $^{-1-}$ mice were not shown as no bacterial counts have been observed. Consistent with these data, CSF samples from infected iNOS ${ }^{-1-}$ mice showed no bacterial growth, whereas $>90 \%$ wild-type animals were positive for meningitis (Figure 3E). We also infected another group of NOS $^{-1}$ mice with a 100-fold higher number of bacteria to examine the resistance of these mice for infection. Of note, none of these animals showed positive signs for meningitis and survived well, similar to that of uninfected animals (Supplemental Figure S3, see http://ajp.amjpathol.org). In contrast, $90 \%$ of wild-type mice infected with a higher dose of bacteria succumbed to infection by 48 hours postinfection. Histopathology of the brain sections of infected $\mathrm{iNOS}^{-1-}$ mice demonstrated no evidence of damage to the brain and were similar to that of uninfected animals (Figure 3F). Because the BBB leakage is hallmark of neonatal meningitis, we next examined the BBB leakage by using Evans blue extravasation method. ${ }^{44,45}$ The dye was injected IP at 72 hours postinfection, and after two hours the brains were removed and Evans blue concentration was determined. A marked increase in the permeability of the BBB was observed in infected wild-type animals, which was significantly reduced in $\mathrm{iNOS}^{-1-}$ mice (Evans blue concentration, 39 $\mu \mathrm{g} / \mathrm{mg}$ protein for wild-type mice versus $4 \mu \mathrm{g} / \mathrm{mg}$ protein for iNOS $^{-1-}$ mice, $P<0.001$ by Student $t$ test) (Figure 3G). These data demonstrate that lack of $\mathrm{NO}$ production in mice is protective against $E$. coli induced brain damage and BBB permeability.

\section{Administration of iNOS Inhibitor, Aminoguanidine Prevents E. coli K1 Meningitis in Mice}

Because lack of NO production increased the clearance of E. coli from circulation, the effect of iNOS inhibitor, AG, on $E$. coli meningitis was assessed. Wild-type mice were pretreated with $A G$ ( $10 \mathrm{mg} / \mathrm{kg}$ body wt) every 12 hours for two days before infecting with $E$. coli on Day 3. The progression of bacterial load in wild-type mice pretreated with $A G$ was found to be similar to that of iNOS ${ }^{-1-}$ mice, and no bacteria were detected by 12 hours postinfection (Figure 4A). However, this was not because of lack of entry of bacteria into blood as the bacterial load increased from $2.22 \log _{10}$ cfu $\mathrm{ml}^{-1}$ at 2 hours to $3.67 \log _{10} \mathrm{cfu} \mathrm{ml}^{-1}$ at 4 hours postinfection. In some experiments, wild-type mice were infected with E. coli, allowed to develop bacteremia by 24 hours postinfection, and then administered a similar dose of $A G$ as in pretreatment and two more doses at 6-hour intervals after an initial dose. Of note, the bacteremia levels declined with time after 24 hours to undetectable levels by 6 days postinfection. In contrast, animals left without treatment succumbed to infection by 72 hours (Figure 4A). Additionally, NO production in brains of infected animals was also reduced to undetectable amounts in wild-type mice posttreated with AG (Figure 4B). AG pretreatment, however, completely suppressed the production of $\mathrm{NO}$ from initial stages of infection. Posttreatment with AG significantly decreased iNOS expression to the levels observed in unin- 
A

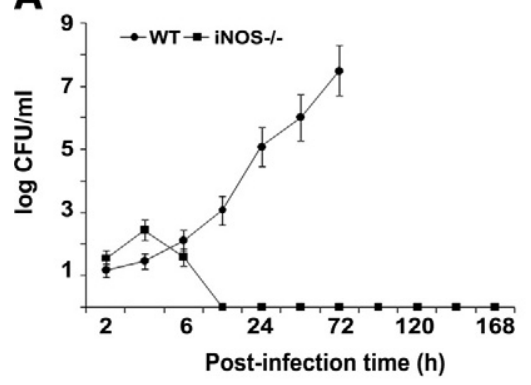

D

C

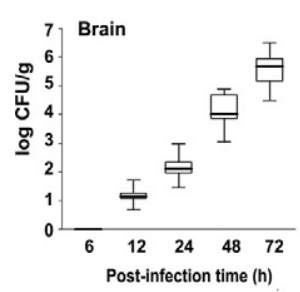

F Cortex and meninges
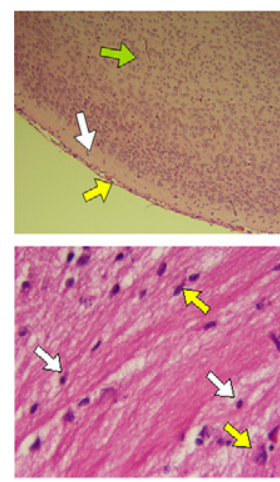

White matter

Hippocampus

Choroid plexus
B

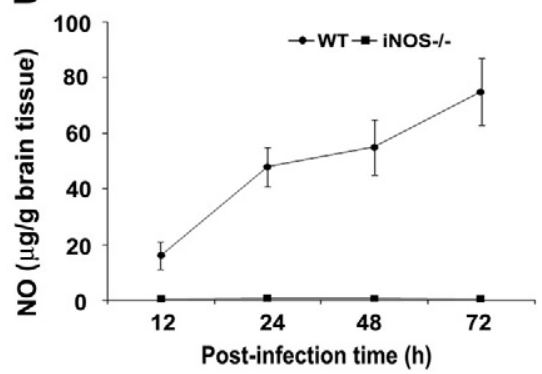

E
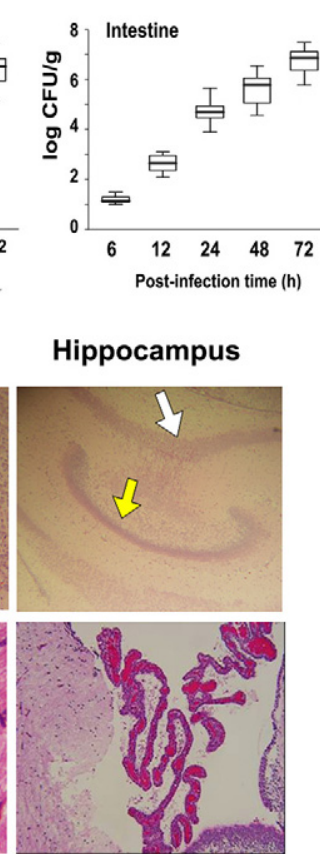

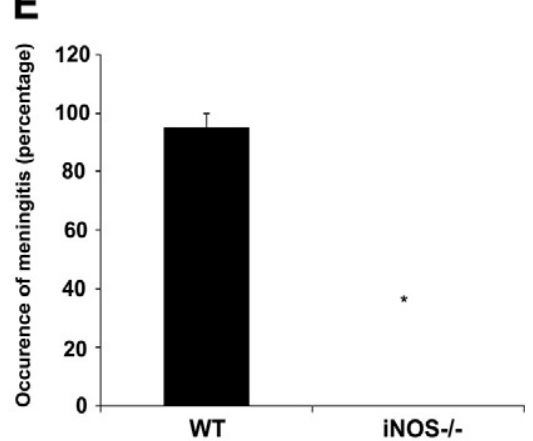

G

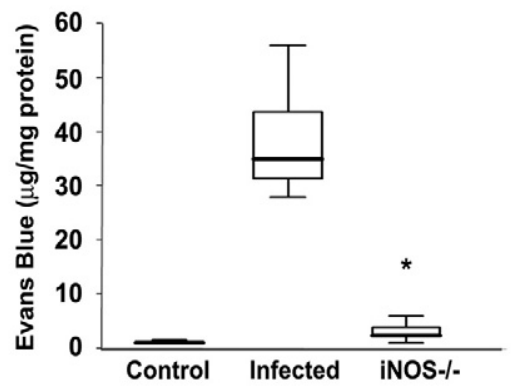

Figure 3. $\mathrm{iNOS}^{-/-}$mice are resistant to $E$. col K1 meningitis. Wild-type (WT) or iNOS ${ }^{-/-}$mice at day 3 were infected with $10^{3}$ cfu of $E$. coli, and blood was collected at different postinfection time points to determine the bacteremia (A). NO production in the brain (B), the bacterial load in brain $(\mathbf{C})$, and the intestine (D) of wild-type mice was determined after sacrificing the animals 72 hours postinfection. Cerbrospinal fluid (CSF) from wild-type and iNOS $^{-/-}$mice at 72 hours postinfection were cultured in antibiotic containing Luria broth to assess the occurrence of meningitis (E). Brains from the infected iNOS ${ }^{-/}$mice were removed and subjected to histopathological examination after H\&E staining (F). The leptomeninges (yellow arrow) in iNOS ${ }^{-/-}$infected mice are thin and apposed to the brain surface. The low cellularity in the molecular layer (white arrow) is normal and the neuronal population (green arrow) is intact. The hippocampal formation is normally folded and the neuronal cellularity in both the dentate gyrus (yellow arrow) and Ammon horn (white arrow) was normal in iNOS ${ }^{-/-}$infected mice. White matter showed normal glial cellularity (astrocytes yellow arrow, oligodendrocytes white arrow). Chroid plexus was also normal. The blood-brain barrier permeability was assessed using the Evans blue extravasation technique $(\mathbf{G})$. Data represent the mean \pm SEM The results are representative of six independent experiments. ${ }^{*} P<0.05$ by Student $t$ test. fected control mice by 168 hours postinfection, whereas pretreatment prevented iNOS expression completely by 6 hours (Figure 4C). AG treated mice showed negative CSF cultures even at 168 hours postinfection, whereas infected but untreated mice showed positive CSF cultures by 72 hours (Figure 4D). In addition, administration of AG markedly improved the survival of infected animals. Wild-type animals died before 96 hours, whereas AG treated mice survived until 168 hours postinfection (see Supplemental Figure S4A at http://ajp.amjpathol.org). Histopathological analysis of wild-type infected and treated with AG revealed no damage to the brain and was similar to that of uninfected animals (see Supplemental Figure S4B at http://ajp.amjpathol.org). In addition, disruption of the BBB was completely attenuated in AG treated animals (Figure $4 \mathrm{E})$. Evans blue concentration in wild-type infected mice was $40 \mu \mathrm{g} / \mathrm{mg}$ protein, which was decreased to $3 \mu \mathrm{g} / \mathrm{mg}$ protein in AG pretreated animals and to $6 \mu \mathrm{g} / \mathrm{mg}$ protein in AG posttreated mice. These results suggest that administration of AG after the development of bacteremia completely clears the pathogen load from the blood and prevented brain damage induced by E. coli. iNOS-derived NO has been shown to play an important role in regulating the cytokine production in different models of infection and inflammation. ${ }^{46}$ In addition, increased production of cytokines during meningitis is known to contribute substantially to organ pathology. Therefore, we investigated the cytokine levels in serum and brain of infected mice. The serum levels of TNF- $\alpha, \mathrm{IL}-1 \beta, \mathrm{IL}-6$, and IL-12 in wild-type animals were increased with postinfection time (Figure 5, A-D). In contrast, the levels of all these cytokines were significantly lower in AG pretreated mice ( $P<0.01$ by Student $t$ test). In AG post-treated animals, the cytokine levels at 24 hours postinfection were significantly reduced to undetectable levels by 168 hours. Similarly significant increase in the levels of all these cytokines was detectable in brains of $E$. coli infected mice compared with control uninfected mice (see Supplementary Figure S5 at http://ajp.amjpathol.org).

\section{AG Administration Restored the Brain Morphology to Normal as Evidenced by Micro-CT Studies}

Although histopathological studies demonstrated that neuronal damage and inflammation of the brain attributable to E. coli infection was significantly reduced by AG treatment, 
A

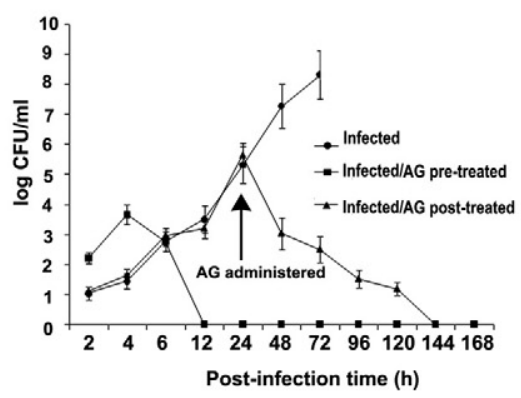

C

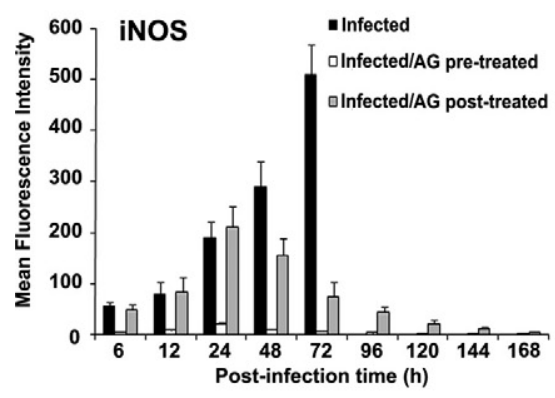

B

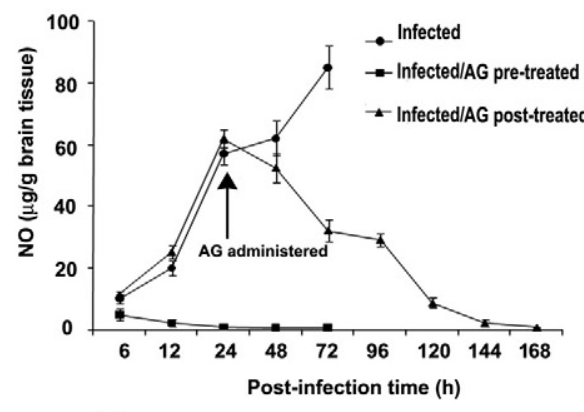

D

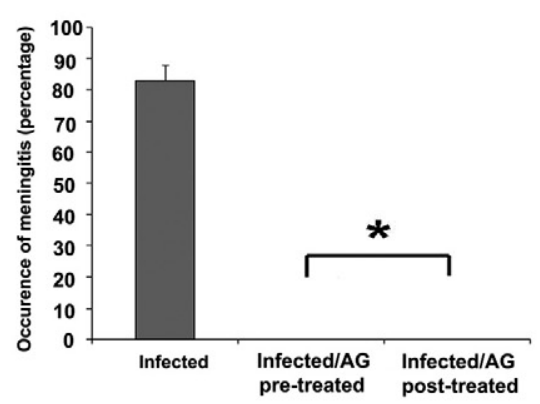

E

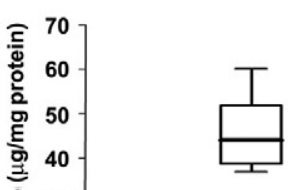

Figure 4. AG treatment protects mice from E. coli $\mathrm{K} 1$ meningitis. Newborn mice ( 1 day old) were pretreated with AG ( $10 \mathrm{mg} / \mathrm{kg}$ body weight) as described in the Materials and Methods and infected with $10^{3} \mathrm{cfu}$ of E. coli on day 3 (Infected/AG pretreated). In some experiments, the animals were infected on day 3 , and then injected with AG after 24 hours postinfection (Infected/AG posttreated). A: Blood was collected at various postinfection time periods; dilutions were made, and plated on antibiotic containing LB agar plates to determine the bacteremia levels. NO production $(\mathbf{B})$ and iNOS expression $(\mathbf{C})$ were determined in the brains of the infected mice. D: The occurrence of meningitis was assessed by culturing CSF samples in antibiotic containing broth. E: Evans blue extravasation was used to assess the blood-brain barrier permeability as described in the Materials and Methods. Data represent the mean \pm SEM. The results are representative of six independent experiments. ${ }^{*} P<0.05$ by Student $t$ test.

it is difficult to assess pathology of a whole brain. Therefore, to further evaluate the brain damage in E. coli K1-infected mice, virtual histology (Micro-CT) analysis was performed. Both control and infected brains were imaged after 72 hours of $E$. coli infection, whereas the brains of AG-treated animals were imaged at 168 hours postinfection. Coronal sections of mouse brains of animals infected with $E$. coli $\mathrm{K} 1$ revealed a significant loss of neurons in the cortical area along with hydrocephalus and dilation of ventricles (Figure 6, A and B, and see Supplemental Videos V1 and V2 at http:// ajp.amjpathol.org). In contrast, these changes were not seen in AG-treated mice (Figure 6C, and see Supplemental Video V3 at http://ajp.amjpathol.org). Analysis of volumetric figures of the brains revealed that $E$. coli infection damaged the forebrain of mice after 72 hours postinfection, whereas AG post-treatment completely prevented the damage (Figure 6, D-F). AG pretreatment also showed similar recovery of the brain (data not shown). Because AG-treated animals were subjected to micro-CT after 168 hours postinfection, the head was larger than the control and infected animals. These data suggest that inhibition of iNOS expression rescues the animals from $E$. coli induced brain damage.

\section{Blood from iNOS ${ }^{-1-}$ or AG Pretreated Mice Demonstrate an Increased Capacity to Kill E. coli $K 1$}

To investigate whether the resistance of $\mathrm{NOS}^{-1-}$ mice could be the result of an intrinsic effect in the ability of blood from iNOS ${ }^{-1-}$ mice to kill E. coli, we performed whole blood survival assays ex vivo. There was a significant increase in killing of $E$. coli in blood from neonatal $\mathrm{iNOS}^{-1-}$ or AG pretreated mice compared with blood taken from wild-type mice $(P<0.001$, by Student $t$ test; see Supplemental Figure S6 at $h$ ttp://ajp.amjpathol.org). More than 50\% bacteria survived in the blood of wild-type animals, whereas only $11 \%$ and $14 \%$ bacteria survived in the blood of iNOS ${ }^{-1-}$ or AG pretreated mice after 60 minutes of incubation and show no production of $\mathrm{NO}$ in these animals (data not shown). These results indicate that resistance of $\mathrm{iNOS}^{-1-}$ or $\mathrm{AG}$ pretreated mice to the occurrence of $E$. coli meningitis may be attributable to increased killing of bacteria in the blood by various immune cells.

\section{iNOS $^{-1-}$ and AG-Treated Macrophages and PMNs Show Enhanced Viability and Increased Phagocytosis of E. coli $K 1$}

Our previous studies have shown that $E$. coli enters and survives in macrophages, which represent an early event in the pathogenesis of $E$. coli meningitis. ${ }^{47}$ Therefore, to examine whether $E$. coli survives in macrophages from $\mathrm{iNOS}^{-1-}$ mice, peritoneal macrophages were isolated from wild-type and $\mathrm{NOS}^{-1-}$ mice and infected with $E$. coli in vitro. Wild-type macrophages engulfed up to $50 \%$ of added E. coli, whereas $80 \%$ of the bacteria were taken up by AG-treated or $\mathrm{iNOS}^{-1-}$ macrophages at two hours 


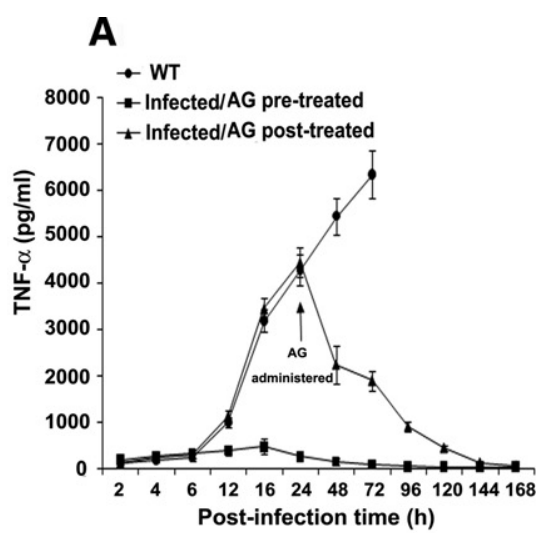

B

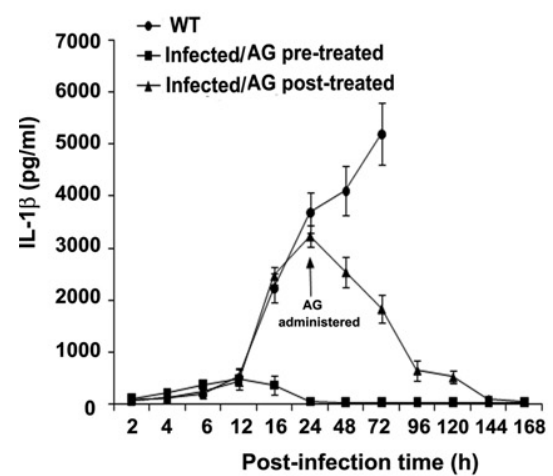

C

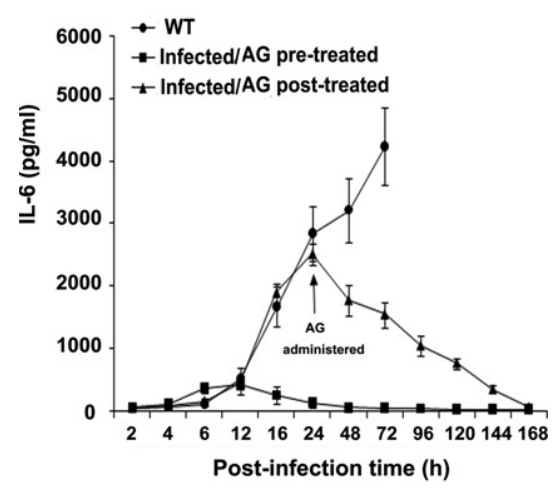

D

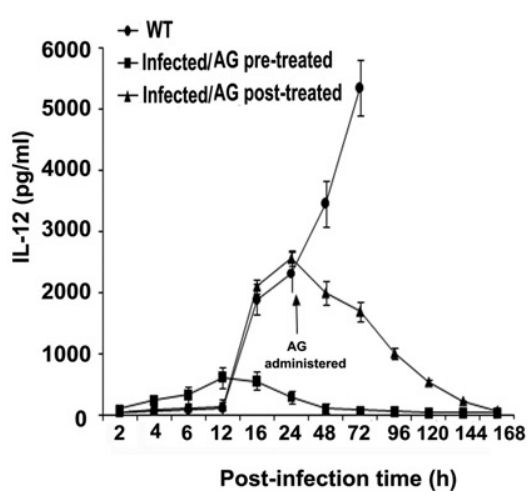

Figure 5. AG treatment ameliorates the cytokine production in serum of $E$ col $i \mathrm{~K} 1-$ infected mice. Blood was collected from infected wild-type (WT), AG pre- or post-treated animals, and the production of TNF- $\alpha(\mathbf{A})$, IL-1 $\beta(\mathbf{B})$, IL-6 (C), and IL-12 (D) in serum was determined by ELISA. The error bars represent mean \pm SEM. The results are representative of five independent experiments performed in triplicate. postinfection, which was further increased by six hours (Figure 7A). The bacteria that entered the wild-type macrophages subsequently multiplied by six hours postinfection, whereas the bacteria in macrophages from iNOS ${ }^{-1-}$ or wild-type macrophages pretreated with AG could not survive efficiently (Figure 7B), indicating that lack of NO enhanced the killing of $E$. coli by macrophages. Because NO has been associated with the viability of macrophages ${ }^{48}$ we assessed the iNOS activity and viability of these cells infected with E. coli. Peritoneal macrophages from wild-type mice infected with $E$. coli exhibited higher iNOS expression and consequently higher NO production (Figure 7, C and D). This higher iNOS-derived NO production correlated with the loss of viability of the cells as determined by Annexin $V$ staining (Figure 7E). In contrast, iNOS ${ }^{-1-}$ and AG-treated macrophages demonstrated significantly lower iNOS expression and consequently more viability of the cells $(P<0.05$ by Student $t$ test). Because PMNs are the first cells to recruit to the sites of infection, we also examined the phagocytosis of E. coli K1 by PMNs. Similar to that of macrophages, PMNs showed enhanced uptake and killing of bacteria by iNOS $^{-1-}$ or AG pretreated cells compared with wild-type PMNs where E. coli K1 survives and multiplies (see Supplementary Figure S7, A and B at http://ajp.amjpathol.org). Taken together, this enhanced killing of bacteria by $\mathrm{iNOS}^{-1-}$ or AG pretreated macrophages and PMNs may account for resistance of $\mathrm{NOS}^{-1-}$ or AG-treated mice to $E$. coli K1 meningitis. These data suggest that lack of NO production increases the phagocytosis of $E$. coli by both PMNs and macrophages.

\section{Modulation of Surface Receptor Expression on Macrophages during E. coli K1 Infection}

Our studies have shown that $E$. coli interacts with CD64 to enter and survive in macrophages (unpublished data). In addition, the bacterium uses gp96 as a receptor on human brain microvascular endothelial cells to invade. ${ }^{49}$ Macrophages also express gp96 and is shown to be responsible for regulating the innate immunity in animals. ${ }^{50}$ Therefore, it is possible that the route of $E$. coli entry into macrophages or other eukaryotic cells dictates the fate of $E$. coli whether they survive or are susceptible to phagocytosis. Several surface receptors on macrophages have been implicated in the uptake of bacteria, however many pathogens devise strategies to subvert the phagocytic mechanisms and survive in the host. ${ }^{51,52}$ Therefore, to evaluate whether the observed differences in phagocytosis by wild-type versus iNOS ${ }^{-1-}$ macrophages may be attributed to variations in receptors expressed on the surface of macrophages, flow cytometry was performed. Macrophages from wild-type mice infected with E. coli showed increased expression of TLR2, gp96, and CD64 and low levels of CR3 and TLR4 compared with control uninfected macrophages (Figure 8, A to E). In contrast, iNOS ${ }^{-1-}$ and AG-treated macrophages infected with $E$. coli showed enhanced expression of CR3 and TLR4 and very low levels of TLR2 and gp96 and moderate levels of CD64, indicating that 
Control
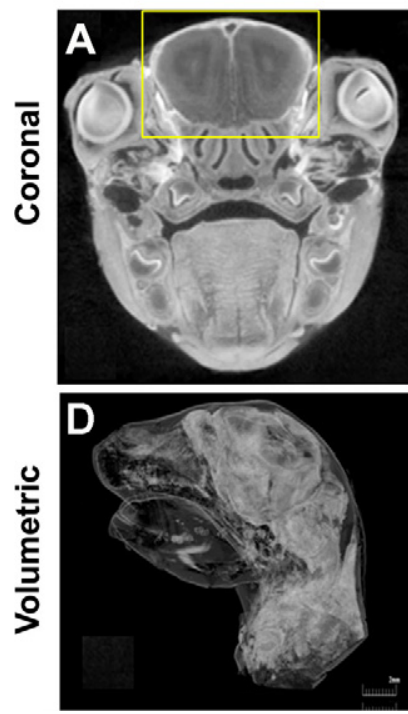

Infected
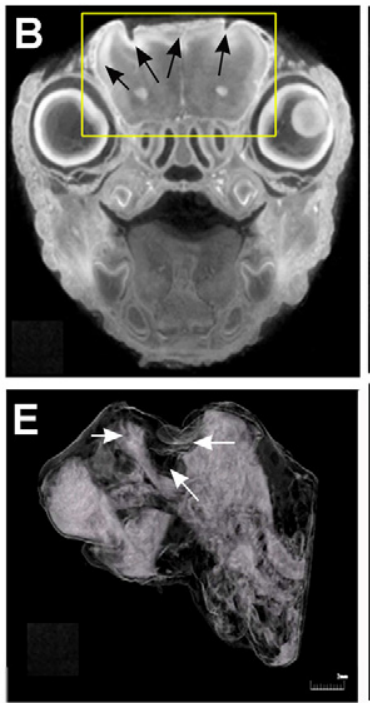

\section{Infected/AG treated}
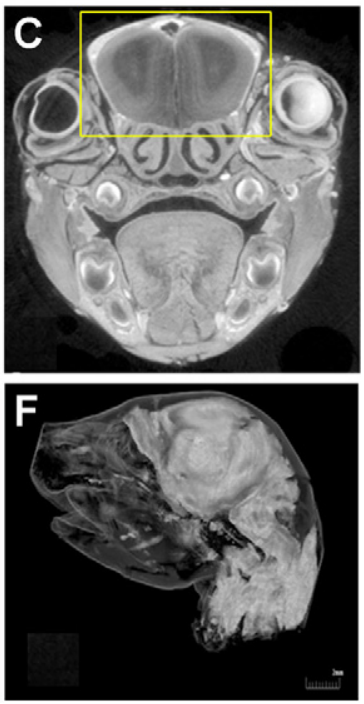

Figure 6. Micro-CT analysis of the brains of $E$ coli K1-infected mice. Newborn mice at day three were infected with $10^{3} \mathrm{cfu}$ of $E$. coli and post-treated with AG. The control and infected animals were sacrificed at 72 hours, whereas AG-treated animals were sacrificed at 168 hours postinfection. The animals were processed for virtual histology as described in the Materials and Methods. Coronal sections and volumetric analysis of brains of newborn mice infected with E. coli $\mathrm{K} 1$ showing significant loss of neurons in the cortical area ( $\mathbf{B}$ and $\mathbf{E}$; indicated by arrows and yellow boxes) compared with uninfected animals (A and $\mathbf{D}$ ). This brain damage was completely prevented in AG-treated animals $(\mathbf{C}$ and $\mathbf{F}$ ).
iNOS suppression decreases the expression of CD64 and gp96 that may be required for bacteria to enter and survive in macrophages. The role of TLR2 in macrophages in the pathogenesis of $E$. coli is still to be determined. Analysis of peritoneal macrophages from wild-type, iNOS ${ }^{-1-}$, and AG-treated mice infected with E. coli also demonstrated that the surface expression pattern was similar to in vitro studies (see Supplemental
Figure S8 at http://ajp.amjpathol.org). These data provide first evidence that modulation of $\mathrm{NO}$ production by macrophages during $E$. coli infection alters the surface expression of phagocytic and pathogen-associated recognition receptors on macrophages. The studies also provide evidence that gp96 recruits to the surface on infection with $E$. coli, which might be playing a role in the survival of $E$. coli.

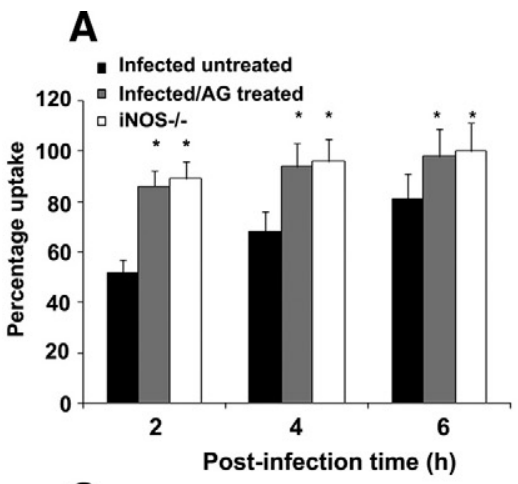

\section{C}

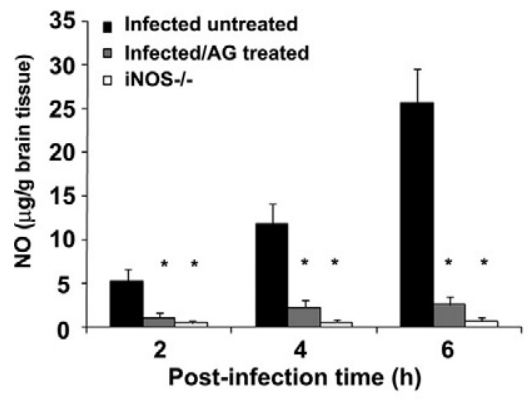

B

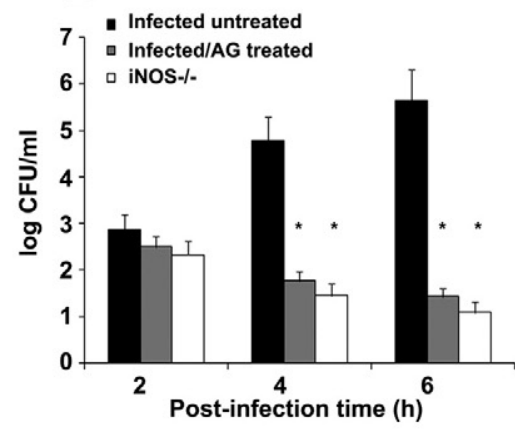

D

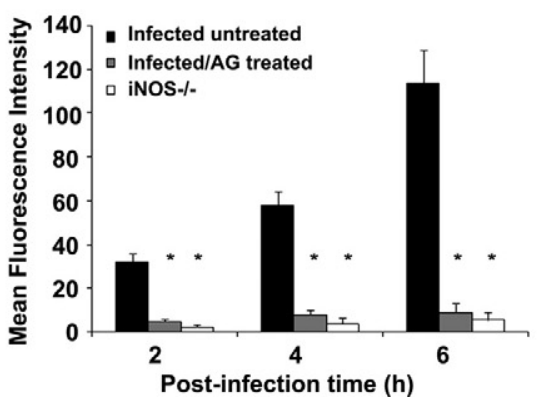

E

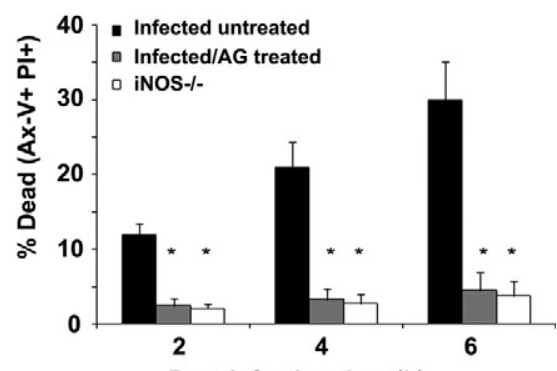

Post-infection time (h)

Figure 7. Phagocytosis, NO production and viability of macrophages infected with $E$. coli $\mathrm{K} 1$ in vitro. Peritoneal macrophages were isolated from wild-type (WT) and iNOS ${ }^{-1-}$ mice and infected with bacteria at a multiplicity of infection of 10 (cell to bacteria ratio, 1:10) for 2, 4, and 6 hours in vitro. In some experiments, macrophages from wild-type mice were also treated with AG $(0.5 \mathrm{mmol} / \mathrm{L})$ for 1 hour before infection. Percentage uptake (A) and intracellular killing (B) of $E$ coli were determined as described in the Materials and Methods. In addition, NO production (C) and iNOS expression (D) were examined in infected macrophages by Griess reagent and flow cytometry, respectively. E: Viability of the infected macrophages was determined using Annexin-V kit according to the manufacturer's instructions. Data represent the mean \pm SEM. The results are representative of six independent experiments performed in triplicate. ${ }^{*} P<0.05$ by Student $t$ test. 
A

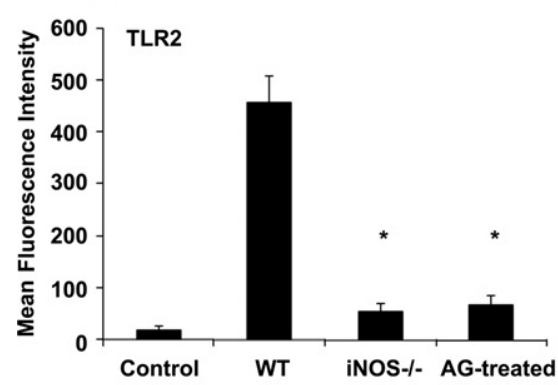

C

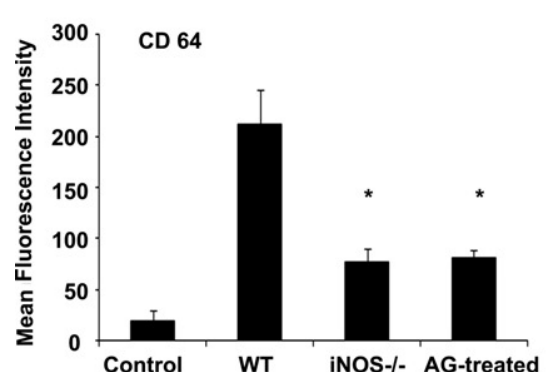

B

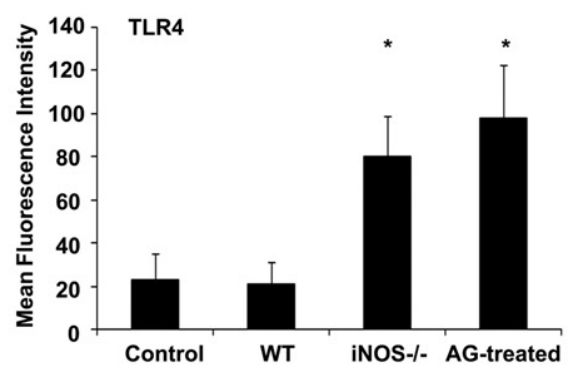

D

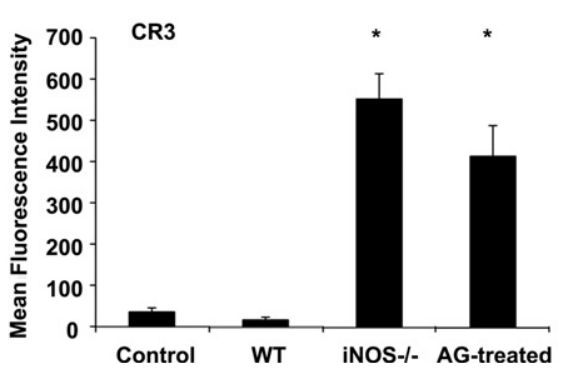

Figure 8. Receptor profile of macrophages infected with E. coli K1. Peritoneal macrophages isolated from wild-type (WT) or iNOS ${ }^{-/}$mice or AG-treated macrophages were infected with E. coli for 6 hours in vitro. After incubation, the cells were washed, fixed, stained for TLR2 (A), TLR4 (B), CD64 (C), CR3 (D), gp96 (E), and analyzed by flow cytometry. Results are expressed as mean fluorescence intensity subtracted from isotype matched control and respective uninfected controls. The error bars represent mean \pm SEM of triplicate samples. The results are representative of five independent experiments. ${ }^{*} P<0.01$ by Student $t$ test.

\section{E}

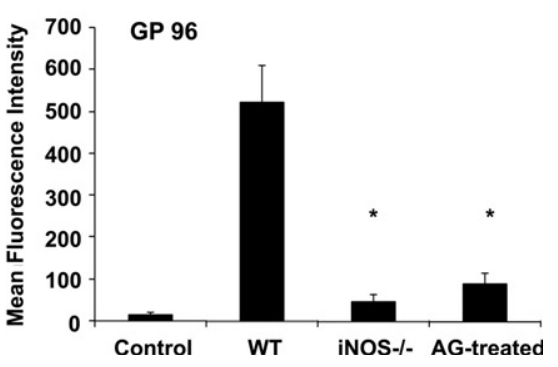

\section{Discussion}

E. coli $\mathrm{K} 1$ is one of the most common pathogens that causes life-threatening sepsis and meningitis in neonates. ${ }^{9-12}$ Lack of knowledge about the pathogenesis of the disease has hindered the development of new therapeutic strategies and contributed to significant mortality and morbidity associated with $E$. coli $\mathrm{K} 1$ meningitis. To understand the pathogenesis of the disease, availability of an acceptable animal model is the foremost requirement. Previously, a newborn rat model of hematogenous meningitis was used by intracardiac injection of the bacteria to understand the pathogenic mechanisms of $E$. coli $\mathrm{K} 1$ meningitis in our laboratory. ${ }^{43}$ Nonetheless, this model circumvents the steps involved in the pathogenesis during the initial stages of infection. In the present study, an attempt was made to establish meningitis model in newborn mouse and rat by using intranasal inoculation with $E$. coli, which is the natural route of entry for this pathogen in humans. In this model, our studies demonstrated that intranasal inoculation with $10^{3}$ cfu of $E$. coli once at day 3 was sufficient to cause meningitis within 72 hours of postinfection.

$\mathrm{NO}$ is a short-lived highly reactive molecule that exerts anti-microbial effects against many bacteria and plays a role in host-cell apoptosis. ${ }^{22-24,26,30,53}$ In addition, NO has been shown to be involved in the vascular permeability. ${ }^{34}$ However, the role of NO has not been documented in E. coli K1 meningitis. The present study for the first time demonstrated that $E$. coli $\mathrm{K} 1$ meningitis dramatically induces NO production in the CNS. Increased transcription of iNOS was responsible for increased NO production in this model. Immunocytochemistry revealed iNOS protein staining in white matter, meninges, and faint staining in the brain parenchyma colocalizing with the inflammatory cells. These results are similar to the findings of elevated NO production during bacterial menin- gitis in human patients as well as in rodents. ${ }^{17,35}$ Neisseria meningitidis, another causative agent of meningitis in neonates, has also been shown to augment NO production during meningitis. ${ }^{54}$ This pathogen possesses NO detoxification system that helps in resisting the bactericidal action of NO for the survival in macrophages. ${ }^{55}$ In agreement with the role of $\mathrm{NO}$ in $E$. coli meningitis, iNOS ${ }^{-1-}$ mice are resistant to infection. NO has been shown to exert beneficial, detrimental, or no effects on disease severity and brain injury, depending on the model and the bacteria studied. For example, lack of eNOS-derived NO aggravates pneumococcal meningitis, whereas iNOSmediated production of $\mathrm{NO}$ controls the bacterial burden in case of Campylobacter jejuni. ${ }^{56,57}$ A compelling observation of our studies is that the inhibition of iNOS activity by its specific inhibitor, AG, completely prevented the disease. Furthermore, posttreatment with $A G$ after the development of high-level bacteremia also rescued the animals from the infection and the brain damage by E. coli. Both immunocytochemistry and virtual histology data showed that the damage caused by $E$. coli to the brain of infected animals reversed to normal condition after AG administration, which is a very important measure to develop novel therapeutic strategies targeting NO produced by iNOS activation. In contrast, pretreatment of newborn rats with $A G$ aggravated the disease severity in Group B streptococcus-induced meningitis. ${ }^{58}$ The method of bacterial inoculation and the dose of $A G$ given to animals by these investigators were different from the methods used in this study. Nonetheless, the neuroprotective and neurodestructive effects of $\mathrm{NO}$ in different models may depend on its oxidized or reduced status. ${ }^{59}$ Although AG has a number of pharmacological actions in addition to inhibition of iNOS that may play a role in bacterial clearance, however the resistance of $\mathrm{iNOS}^{-1-}$ mice to $E$. coli $\mathrm{K} 1$ 
meningitis clearly substantiate the role of $\mathrm{NO}$ in the pathogenesis of meningitis by E. coli $\mathrm{K} 1$.

Cytokines are important mediators of the inflammatory reaction to bacterial challenge. Elevated CSF levels of TNF- $\alpha, I L-1 \beta, I L-12$, and IL- 6 have been observed in patients with bacterial meningitis, and the concentration of TNF- $\alpha$ was significantly correlated with the clinical outcome of the disease. ${ }^{60,61}$ In rodent models of bacterial meningitis, brain mRNA as well as protein expression of TNF- $\alpha, I L-1 \beta$, and IL- 6 were upregulated in the acute stage of the inflammation. ${ }^{62}$ In this study, significant enhancement in the levels of TNF- $\alpha$, IL- $1 \beta, \mathrm{IL}-12$, and IL- 6 was observed in the serum and brain tissues of infected mice but not in $\mathrm{iNOS}^{-1-}$ and AG-treated mice. These data within the context of bacteremia levels observed in iNOS $^{-1-}$ and AG-treated mice implicate that amplification of immune response could be related to the number of bacteria in circulation. It has been reported that NO induced by Salmonella species ${ }^{63}$ and Actinobacillus species $^{64}$ has anti-apoptotic activity, whereas NO induced by Helicobacter pylori ${ }^{65}$ and Mycobacterium tuberculosis ${ }^{66}$ has pro-apoptotic activity. NO production by $E$. coli in macrophages also induced apoptosis of the cells although to a lower extent; however, the bacterial entry into macrophages induces anti-apoptotic mechanisms by triggering the expression of $\mathrm{Bcl}-\mathrm{XL}$ as shown in our previous studies. ${ }^{67}$ Therefore, NO plays a dichotomous role in animal models of infections. Of note, the resistance of $E$. coli to NO may be related to the genes that encode proteins associated with detoxification mechanisms or resistance to oxygen/nitrogen radicals.

The BBB is a regulatory interface between the peripheral circulation and the central nervous system. ${ }^{68}$ Neurological manifestations caused by neuroinvading pathogens are typically attributed to penetration of the BBB and invasion of the CNS. ${ }^{44,45}$ Disruption of the BBB is an important hallmark of bacterial meningitis. Breaching of the $\mathrm{BBB}$ results in the formation of brain edema with raised intracranial pressure, which often accounts for an adverse clinical outcome in patients with bacterial meningitis. We observed that infection with $E$. coli lead to significant BBB disruption as indicated by the leakage of Evans blue into brain tissues of infected mice. However, the BBB permeability was significantly attenuated in iNOS $^{-1-}$ and AG-treated infected mice. These results confirm that $\mathrm{NO}$ is an important modulator of BBB permeability during $E$. coli meningitis. In agreement with these findings, our studies with HBMECs revealed that $E$. coli infection of HBMECs induces significant production of $\mathrm{NO}$, which in turn is responsible for the permeability of HBMEC monolayer. ${ }^{36}$ Furthermore, NO donors significantly induced the leakage of HBMEC monolayers via cGMP and PKC- $\alpha$ activation. However, it is possible that lack of BBB leakage in AG-treated animals could be partly attributable to reduced inflammatory response.

Macrophages are the most important immune cells; they play an essential role in the clearance of pathogens. ${ }^{69,70}$ Because the phagocytosis of $E$. coli increased in $\mathrm{iNOS}^{-1-}$ macrophages or AG-treated macrophages, it is possible that efficient antimicrobial responses could be elicited in these cells. Moreover, the expression of recep- tors on the macrophages may be important in determining whether a macrophage kills the pathogen or surrenders to the microbe. ${ }^{69}$ TLR2, TLR4, CR3, gp96, and CD64 (Fc $\gamma \mathrm{l})$ have been shown to play an important role directly or indirectly in the phagocytic ability of macrophages. ${ }^{50,71-79}$ Therefore, in the present study, expression of these receptors was determined on the surface of E. coli K1 infected macrophages. Interaction of macrophages with microbes can alter macrophage responsiveness by increasing the affinity of receptors for their targets or by coupling receptors to new intracellular signaling pathways. ${ }^{80,81}$ Consistent with this concept, $E$. coli infection increased the expression of TLR2, gp96, and CD64 and suppressed the expression of CR3 and TLR4. These macrophages showed reduced phagocytosis and killing of E. coli. In contrast, peritoneal macrophages from iNOS $^{-1-}$ or AG-treated macrophages showed higher levels of CR3, moderate levels of TLR4, and very low levels of TLR2, gp96, and CD64. These macrophages efficiently killed $E$. coli, which may be attributed to enhanced viability of these immune cells. Taken together these results showed that $E$. coli $\mathrm{K} 1 \mathrm{mod}-$ ulates the phagocytic ability and receptor expression on the surface of macrophages, which may help the pathogen survive and multiply inside these cells. This may be a crucial step in reaching the high degree of bactremia required to cross the $\mathrm{BBB}$ and cause meningitis.

In summary, the present study revealed three novel aspects involved in the pathogenesis of meningitis by $E$. coli K1. First, increased production of $\mathrm{NO}$ is required for the survival and multiplication of $E$. coli during early stages of infection. Second, E. coli interaction with macrophages modulates the surface expression of pathogen recognition receptors and thereby suppresses the phagocytic ability of the macrophages. Third, prevention of brain damage, BBB permeability, and the occurrence of meningitis by treating $E$. coli infected animals with an inhibitor of iNOS activation after the development of highlevel bacteremia. The last observation is a key for developing new therapeutic strategies to prevent $E$. coli meningitis in neonates by targeting inducible nitric oxide, as diagnosis of $E$. coli infection is difficult until the bacteria reaches to a certain threshold level. Further understanding of the complex interactions between E. coli K1 and macrophages are important to the identification of novel interventional strategies that can improve the outcome of this deadly disease.

\section{References}

1. Somand D, Meurer W: Central nervous system infections. Emerg Med Clin North Am 2009, 27:89-100

2. Dawson KG, Emerson JC, Burns JL: Fifteen years of experience with bacterial meningitis. Pediatr Infect Dis J 1999, 18:816-822

3. Sinner SW, Tunkel AR: Antimicrobial agents in the treatment of bacterial meningitis. Infect Dis Clin North Am 2004, 18:581-602

4. Stoll BJ: The global impact of neonatal infection. Clin Perinatol 1997 24:1-21

5. Tebruegge M, Curtis N: Epidemiology, etiology, pathogenesis, and diagnosis of recurrent bacterial meningitis. Clin Microbiol Rev 2008, 21:519-537 
6. Tunkel AR, Scheld WM: Pathogenesis and pathophysiology of bacterial meningitis. Clin Microbiol Rev 1993, 6:118-136

7. Polin RA, Harris MC: Neonatal bacterial meningitis. Semin Neonatol 2001, 6:157-172

8. Scheld WM, Koedel U, Nathan B, Pfister HW: Pathophysiology of bacterial meningitis: mechanism(s) of neuronal injury. J Infect Dis 2002, 186:S225-S233

9. Mulder CJ, van Alphen L, Zanen HC: Neonatal meningitis caused by Escherichia coli in the Netherlands. J Infect Dis 1984, 150:935-940

10. de Louvois J, Blackbourn J, Hurley R, Harvey D: Infantile meningitis in England and Wales: a two year study. Arch Dis Child 1991, 66:603-607

11. Houdouin V, Bonacorsi S, Bidet P, Blanco J, De La Rocque F, Cohen $\mathrm{R}$, Aujard $\mathrm{Y}$, Bingen $\mathrm{E}$ : Association between mortality of Escherichia coli meningitis in young infants and non-virulent clonal groups of strains. Clin Microbiol Infect 2008, 14:685-690

12. Bonacorsi S, Bingen E: Molecular epidemiology of Escherichia coli causing neonatal meningitis. Int J Med Microbiol 2005, 295:373-381

13. Bizzarro MJ, Dembry LM, Baltimore RS, Gallagher PG: Changing patterns in neonatal Escherichia coli sepsis and ampicillin resistance in the era of intrapartum antibiotic prophylaxis. Pediatrics 2008, 121:689-696

14. Ramdani-Bouguessa N, Mendonça N, Leitao J, Ferreira E, Tazir M, Caniça M: CTX-M-3 and CTX-M-15 extended-spectrum $\beta$-lactamases in isolates of Escherichia coli from a hospital in Algiers. Algeria J Clin Microbiol 2006, 44:4584-4586

15. Boyer-Mariotte S, Duboc P, Bonacorsi S, Lemeland JF, Bingen E, Pinquier D: CTX-M-15-producing Escherichia coli in fatal neonatal meningitis: failure of empirical chemotherapy. J Antimicrob Chemother 2008, 62:1472-1474

16. Kim KS: Pathogenesis of bacterial meningitis: from bacteraemia to neuronal injury. Nat Rev Neurosci 2003, 4:376-385

17. Suzuki Y, Fujii S, Tominaga T, Yoshimoto T, Fujii S, Akaike T, Maeda $\mathrm{H}$, Yoshimura T: Direct evidence of in vivo nitric oxide production and inducible nitric oxide synthase mRNA expression in the brain of living rat during experimental meningitis. J Cereb Blood Flow Metab 1999, 19:1175-1178

18. Kornelisse RF, Hoekman K, Visser JJ, Hop WC, Huijmans JG, van der Straaten PJ, van der Heijden AJ, Sukhai RN, Neijens HJ, de Groot R: The role of nitric oxide in bacterial meningitis in children. $\mathrm{J}$ Infect Dis 1996, 174:120-126

19. Moncada S, Higgs A: The L-arginine-nitric oxide pathway. N Engl J Med 1993, 329:2002-2012

20. Stuehr DJ: Mammalian nitric oxide synthases. Biochim Biophys Acta 1999, 1411:217-230

21. Nathan C, Xie QW: Nitric oxide synthases: roles, tolls, and controls. Cell 1994, 78:915-918

22. Lowenstein CJ, Dinerman JL, Snyder SH: Nitric oxide: a physiologic messenger. Ann Intern Med 1994, 120:227-237

23. Nathan C: Nitric oxide as a secretory product of mammalian cells FASEB J 1992, 6:3051-3064

24. Galea E, Reis DJ, Feinstein DL: Cloning and expression of inducible nitric oxide synthase from rat astrocytes. J Neurosci Res 1994 37:406-414

25. Nunokawa $Y$, Ishida N, Tanaka S: Cloning of inducible nitric oxide synthase in rat vascular smooth muscle cells. Biochem Biophys Res Commun 1993, 191:89-94

26. Moncada S, Palmer RM, Higgs EA: Nitric oxide: physiology, pathophysiology, and pharmacology. Pharmacol Rev 1991, 43:109-142

27. Bogdan $\mathrm{C}$, Rollinghoff M, Diefenbach A: The role of nitric oxide in innate immunity. Immunol Rev 2000, 173:17-26

28. Bogdan C: The multiplex function of nitric oxide in (auto)immunity. $J$ Exp Med 1998, 187:1361-1365

29. Bogdan C, Rollinghoff M, Diefenbach A: Reactive oxygen and reactive nitrogen intermediates in innate and specific immunity. Curr Opin Immunol 2000, 12:64-76

30. Fang FC: Perspectives series: host/pathogen interactions. Mechanisms of nitric oxide-related antimicrobial activity J Clin Invest 1997 99:2818-2825

31. Licinio J, Prolo P, McCann SM, Wong ML: Brain iNOS: current understanding and clinical implications. Mol Med Today 1999, 5:225-232

32. Akaike T, Noguchi Y, ljiri S, Setoguchi K, Suga M, Zheng YM, Dietzschold B, Maeda H: Pathogenesis of influenza virus-induced pneumonia: involvement of both nitric oxide and oxygen radicals. Proc Natl Acad Sci USA 1996, 93:2448-2453
33. Koprowski H, Zheng YM, Heber-Katz E, Fraser N, Rorke L, Fu ZF, Hanlon C, Dietzschold B: In vivo expression of inducible nitric oxide synthase in experimentally induced neurologic diseases. Proc Natl Acad Sci USA 1993, 90:3024-3027

34. Koedel U, Bernatowicz A, Paul R, Frei K, Fontana A, Pfister HW: Experimental pneumococcal meningitis: cerebrovascular alterations, brain edema, and meningeal inflammation are linked to the production of nitric oxide. Ann Neurol 1995, 37:313-323

35. Buster BL, Weintrob AC, Townsend GC, Scheld WM: Potential role of nitric bacterial meningitis oxide in the pathophysiology of experimental bacterial meningitis in rats. Infect Immun 1995, 63:3835-3839

36. Mittal R, Prasadarao NV: Nitric oxide/cGMP signaling induces Escherichia coli $\mathrm{K} 1$ receptor expression and modulates the permeability in human brain endothelial cell monolayers during invasion. Cell Microbiol 2010, 12:67-83

37. Prasadarao NV, Wass CA, Weiser JN, Stins MF, Huang SH, Kim KS: Outer membrane protein A of Escherichia coli contributes to invasion of brain microvascular endothelial cells. Infect Immun 1996, $64: 146-153$

38. Mittal R, Wang Y, Hunter CJ, Gonzalez-Gomez I, Prasadarao NV: Brain damage in newborn rat model of meningitis by Enterobacter sakazakii: a role for outer membrane protein A. Lab Invest 2009, 89:263-277

39. Mittal R, Sharma S, Chhibber S, Hariai K: Contribution of free radicals to Pseudomonas aeruginosa induced acute pyelonephritis. Microb Pathog 2008, 45:323-330

40. Lu B, Figini M, Emanueli C, Geppetti P, Grady EF, Gerard NP, Ansell J. Payan DG, Gerard C, Bunnett N: The control of microvascular permeability and blood pressure by neutral endopeptidase. Nat Med 1997, 3:904-907

41. Mittal R, Sharma S, Chhibber S, Harjai K: Iron dictates the virulence of Pseudomonas aeruginosa in urinary tract infections. J Biomed Sci 2008, 15:731-741

42. Luo Y, Dorf ME: Isolation of mouse neutrophils. Curr Protoc Immunol 2001 Chapter 3:Unit 3.20

43. Prasadarao NV, Wass CA, Kim KS: Endothelial cell GlcNAc beta 1-4GIcNAc epitopes for outer membrane protein A enhance traversal of Escherichia coli across the blood-brain barrier. Infect Immun 1996, 64:154-160

44. Durand ML, Calderwood SB, Weber DJ, Miller SI, Southwick FS, Caviness VS Jr, Swartz MN: Acute bacterial meningitis in adults: a review of 493 episodes. N Engl J Med 1993, 328:21-28

45. Kim KS: Escherichia coli translocation of the blood-brain barrier Infect Immun 2001, 69:5217-5222

46. Paul R, Koedel U, Pfister HW: Development of adjunctive therapies for bacterial meningitis and lessons from knockout mice. Neurocrit Care 2005, 2:313-324

47. Sukumaran SK, Shimada H, Prasadarao NV: Entry and intracellular replication of Escherichia coli $\mathrm{K} 1$ in macrophages require expression of outer membrane protein A. Infect Immun 2003, 71:5951-5961

48. Albina JE, Cui S, Mateo RB, Reichner JS: Nitric oxide-mediated apoptosis in murine peritoneal macrophages. J Immunol 1993, 150:5080-5085

49. Prasadarao NV: Identification of $E$. coli outer membrane protein $A$ receptor on human brain microvascular endothelial cells. Infect Immun 2002, 70:4556-4563

50. Yang Y, Liu B, Dai J, Srivastava PK, Zammit DJ, Lefrançois L, Li Z Heat shock protein gp96 is a master chaperone for toll-like receptors and is important in the innate function of macrophages. Immunity 2007, 26:215-226

51. Isberg RR, O'Connor TJ, Heidtman M: The Legionella pneumophila replication vacuole: making a cosy niche inside host cells. Nat Rev Microbiol 2009, 7:13-24

52. Sansonetti P: Phagocytosis of bacterial pathogens: implications in the host response. Semin Immunol 2001, 13:381-390

53. Hunter CJ, Williams M, Petrosyan M, Guner $Y$, Mittal R, Mock D, Upperman JS, Ford HR, Prasadarao NV: Lactobacillus bulgaricus prevents intestinal epithelial cell injury caused by Enterobacter sakazakii-induced nitric oxide both in vitro and in the newborn rat model of necrotizing enterocolitis. Infect Immun 2009, 77:1031-1043

54. Murawska-Ciatowicz E, Szychowska Z, Trebusiewicz B: Nitric oxide production during bacterial and viral meningitis in children. Int J Clin Lab Reg 2000, 30:127-131

55. Stevanin TM, Moir JW, Read RC: Nitric oxide detoxification systems 
enhance survival of Neisseria meningitidis in human macrophages and in nasopharyngeal mucosa. Infect Immun 2005, 73:3322-3329

56. Koedel U, Paul R, Winkler F, Kastenbauer S, Huang PL, Pfister HW: Lack of endothelial nitric oxide synthase aggravates murine pneumococcal meningitis. J Neuropathol Exp Neurol 2001, 60:1041-1050

57. Iovine NM, Pursnani S, Voldman A, Wasserman G, Blaser MJ, Weinrauch Y: Reactive nitrogen species contribute to innate host defense against Campylobacter jejuni. Infect Immun 2008, 76:986-993

58. Leib SL, Kim YS, Black SM, Tureen JH, Täuber MG: Inducible nitric oxide synthase and the effect of aminoguanidine in experimental neonatal meningitis. J Infect Dis 1998, 177:692-700

59. Lipton SA, Choi YB, Pan ZH, Lei SZ, Chen HS, Sucher NJ, Loscalzo J, Singel DJ, Stamler JS: A redox-based mechanism for the neuroprotective and neurodestructive effects of nitric oxide and related nitroso-compounds. Nature 1993, 364:626-632

60. Waage A, Halstensen A, Shalaby R, Brandtzaeg P, Kierulf P, Espevik $\mathrm{T}$ : Local production of tumor necrosis factor alpha, interleukin 1, and interleukin 6 in meningococcal meningitis. Relation to the inflammatory response. J Exp Med 1989, 170:1859-1867

61. Mustafa MM, Lebel MH, Ramilo O, Olsen KD, Reisch JS, Beutler B, McCracken GH Jr: Correlation of interleukin-1 beta and cachectin concentrations in cerebrospinal fluid and outcome from bacterial meningitis. J Pediatr 1989, 115:208-213

62. Hackett SJ, Thomson AP, Hart CA: Cytokines, chemokines and other effector molecules involved in meningococcal disease. J Med Microbiol 2001, 50:847-859

63. Alam MS, Akaike T, Okamoto S, Kubota T, Yoshitake J, Sawa T, Miyamoto $\mathrm{Y}$, Tamura F, Maeda H: Role of nitric oxide in host defense in murine salmonellosis as a function of its antibacterial and antiapoptotic activities. Infect Immun 2002, 70:3130-3142

64. Nakashima K, Tomioka J, Kato S, Nishihara T, Kowashi Y: Nitric oxide-mediated protection of $\mathrm{A}$. actinomycetemcomitans-infected murine macrophages against apoptosis. Nitric Oxide 2002, 6:61-68

65. Gobert AP, Cheng Y, Wang JY, Boucher JL, Iyer RK, Cederbaum SD, Casero RA Jr., Newton JC, Wilson KT: Helicobacter pylori induces macrophage apoptosis by activation of arginase II. J Immunol 2002, 168:4692-4700

66. Chan ED, Chan J, Schluger NW: What is the role of nitric oxide in murine and human host defense against tuberculosis? Current knowledge. Am J Respir Cell Mol Biol 2001, 25:606-612

67. Sukumaran SK, Selvaraj SK, Prasadarao NV: Inhibition of apoptosis by Escherichia coli $\mathrm{K} 1$ is accompanied by increased expression of $\mathrm{BcIXL}$ and blockade of mitochondrial cytochrome $\mathrm{c}$ release in macrophages. Infect Immun 2004, 72:6012-6022

68. Rubin LL, Staddon JM: The cell biology of the blood-brain barrier. Annu Rev Neurosci 1999, 22:11-28
69. Hunter M, Wang Y, Eubank T, Baran C, Nana-Sinkam P, Marsh C: Survival of monocytes and macrophages and their role in health and disease. Front Biosci 2009, 14:4079-4102

70. Underhill DM, Ozinsky A: Phagocytosis of microbes: complexity in action. Annu Rev Immunol 2002, 20:825-852

71. Taylor PR, Martinez-Pomares L, Stacey M, Lin HH, Brown GD, Gordon S: Macrophage receptors and immune recognition. Annu Rev Immunol 2005, 23:901-944

72. Drevets DA, Leenen PJ, Campbell PA: Complement receptor type 3 (CD11b/CD18) involvement is essential for killing of Listeria monocytogenes by mouse macrophages. J Immunol 1993, 151:5431-5439

73. Drevets DA, Leenen PJ, Campbell PA: Complement receptor type 3 mediates phagocytosis and killing of Listeria monocytogenes by a TNF-alpha- and IFN-gamma-stimulated macrophage precursor hybrid. Cell Immunol 1996, 169:1-6

74. Gafa V, Manches O, Pastor A, Drouet E, Ambroise-Thomas P, Grillot R, Aldebert D: Human cytomegalovirus downregulates complement receptors (CR3. CR4) and decreases phagocytosis by macrophages J Med Virol 2005, 76:361-366

75. Watanabe I, Ichiki M, Shiratsuchi A, Nakanishi Y: TLR2-mediated survival of Staphylococcus aureus in macrophages: a novel bacterial strategy against host innate immunity. J Immunol 2007, 178:4917-4925

76. Higgins SC, Jarnicki AG, Lavelle EC, Mills KH: TLR4 mediates vaccine-induced protective cellular immunity to Bordetella pertussis: role of IL-17-producing T cells.J Immunol 2006, 177:7980-7989

77. Weiss DJ, Souza CD, Evanson OA, Sanders M, Rutherford M: Bovine monocyte TLR2 receptors differentially regulate the intracellular fate of Mycobacterium avium subsp. paratuberculosis and Mycobacterium avium subsp. avium. J Leukoc Biol 2008, 83:48-55

78. Grage-Griebenow E, Flad HD, Ernst M, Bzowska M, Skrzeczyñska J, Pryjma J: Human MO subsets as defined by expression of CD64 and CD16 differ in phagocytic activity and generation of oxygen intermediates. Immunobiology 2000, 202:42-50

79. Ioan-Facsinay A, de Kimpe SJ, Hellwig SM, van Lent PL, Hofhuis FM, van Ojik HH, Sedlik C, da Silveira SA, Gerber J, de Jong YF, Roozendaal R, Aarden LA, van den Berg WB, Saito T, Mosser D, Amigorena S, Izui S, van Ommen GJ, van Vugt M, van de Winkel JG, Verbeek JS: FcgammaRI (CD64) contributes substantially to severity of arthritis, hypersensitivity responses, and protection from bacterial infection. Immunity 2002, 16:391-402

80. Gonzalez-Mejia ME, Doseff Al: Regulation of monocytes and macrophages cell fate. Front Biosci 2009, 14:2413-2431

81. Mosser DM: Receptors on phagocytic cells involved in microbial recognition. Immunol Ser 1994, 60:99-114 